\title{
EVALUATION OF SERUM INTERLEUKIN-6 AND TUMOR NECROSIS FACTOR-ALPHA LEVELS IN PATIENTS WITH DENGUE FEVER - A TERTIARY CARE HOSPITAL BASED STUDY
}

\author{
ROHIN DUBBAL ${ }^{1 *}$, SRIRAM BS ${ }^{2}$ \\ ${ }^{1}$ Department of General Medicine, K.S. Hegde Medical Academy, Mangalore, Karnataka, India. ${ }^{2}$ Department of Pharmacology, K.S. Hegde \\ Medical Academy, Mangalore, Karnataka, India. Email: rohin.dubbal@gmail.com \\ Received: 17 January 2019, Revised and Accepted: 28 February 2020
}

\begin{abstract}
Objective: The objective of the study was to evaluate the levels of serum interleukin-6 (IL-6) and tumor necrosis factor-alpha (TNF- $\alpha$ ) during the course of $3^{\text {rd }}$ and $5^{\text {th }}$ days of dengue infection.

Methods: The prospective cohort study was taken up involving 50 adults diagnosed with dengue fever and admitted to Mysore Medical College and Research Institute from December 2015 to November 2016. Detailed history has been taken and clinical examination was carried out. Venous blood sample was collected and serum separated out for estimation of IL- 6 and TNF- $\alpha$ levels using ELISA.
\end{abstract}

Results: It has been observed that the levels of IL- 6 and TNF- $\alpha$ raised during $3^{\text {rd }}$ day of infection and there is decrease in levels of IL- 6 and no changes have been observed in TNF- $\alpha$ levels during $5^{\text {th }}$ day.

Conclusion: The study concludes that the IL- 6 and TNF- $\alpha$ plays a key role in understanding pathogenesis of severity of dengue infection, TNF- $\alpha$ being more sensitive in reaction to pathogen

Keywords: Interleukin-6, Tumor necrosis factor-alpha, Dengue infection.

(C) 2020 The Authors. Published by Innovare Academic Sciences Pvt Ltd. This is an open access article under the CC BY license (http://creativecommons. org/licenses/by/4. 0/) DOI: http://dx.doi.org/10.22159/ajpcr.2020.v13i4.36877

\section{INTRODUCTION}

Dengue is an leading flavivirus infection transmitted by Aedes mosquitoes of intertropical area which may be due to increased urbanization and air travel [1]. It is characterized by severe plasma leakage, accumulation of fluid, organ impairment and hemorrhages [2] patients presenting with dengue infection can be classified into two groups: One with warning signs of bleeding and hepatosplenomegaly and the other without symptomatic signs $[3,4]$. It has been observed that benign cases turns to severe dengue hemorrhagic fever (DHF) and dengue shock syndrome (DSS) which could be attributed to the host pathogen interaction in which redox state of the body is altered along with changes in inflammatory status, the exact mechanism is poorly understood $[5,6]$. It is very important to screen an ideal biomarker which identifies individuals who are at high risk of developing severe dengue. Thus, the present study aimed at understanding the role of interleukin-6 (IL-6) and tumor necrosis factor-alpha (TNF- $\alpha$ ) in the course of dengue infection.

\section{METHODS}

The prospective cohort study was taken up involving 50 adults diagnosed with dengue fever and admitted to Mysore Medical College and Research Institute from December 2015 to November 2016. Institutional Ethics Committee permission and informed consent have been taken during the study. Information from all patients regarding any comorbid conditions, medications have been collected. Detailed history has been taken and clinical examination was carried out. Venous blood samples were collected and serum separated out for the estimation of IL-6 and TNF- $\alpha$ levels using ELISA.

\section{Inclusion criteria}

Subjects aged more than 18 years, diagnosed as having dengue on the basis of Ig M and NS 1 ELISA test for dengue fever were included in the study.

\section{Exclusion criteria}

Subjects not willing to give consent, subjects suffering from malaria and typhoid, subjects having diabetes mellitus, and subjects suffering from chronic illness such as chronic kidney disease, chronic liver disease, pregnant women, immunocompromised state, and subjects with alcoholic liver disease were excluded from the study.

Statistical analysis was performed during SPSS version 16 . The data were evaluated using paired test. $\mathrm{p}<0.05$ is considered significant.

\section{RESULTS}

IL-6 levels on days $3^{\text {rd }}$ and $5^{\text {th }}$ of dengue infection

On day $3^{\text {rd }}$ of dengue infection, the IL- 6 levels are raised significantly suggesting the role of inflammation associated with infection. On $5^{\text {th }}$ day, the level of IL-6 decreased significantly which is observed in Fig. 1.

TNF- $\alpha$ levels on days $3^{\text {rd }}$ and $5^{\text {th }}$ of dengue infection

On day $3^{\text {rd }}$ of dengue infection, the TNF- $\alpha$ levels are raised significantly which could be attributed to inflammation. Interestingly on the $5^{\text {th }}$ day, the level of TNF- $\alpha$ remained same which is observed in Fig. 2.

\section{DISCUSSION}

Cytokines and other inflammatory mediators play a key role in modulating immune response to dengue infection, but in some cases, it may lead to improper responses in patients. It has been noticed that TNF- $\alpha$ can influence endothelial cells and can lead to activation resulting in DHF/DSS [7].

IL-6 is one of the endogenous acting pro-inflammatory cytokine having greater endothelial permeability. Multiple studies have suggested the role of IL-6 in developing severity of dengue infection which can be noticed during the course of infection and illness severity [8-12]. 


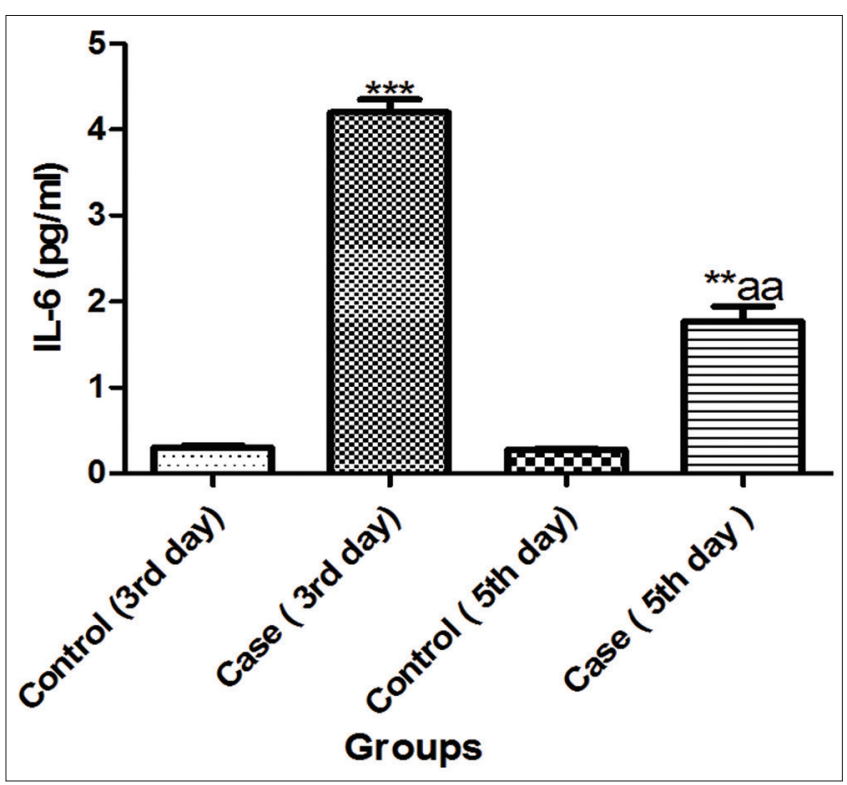

Fig. 1: The result of serum interleukin-6 levels of patients suffering from dengue infection on the $5^{\text {th }}$ and $7^{\text {th }}$ days of hospital admission. Data are expressed as mean \pm standard deviation, $\mathbf{p}<0.05$ is considered significant, ${ }^{* * *} \mathbf{p}=0.001$ compared to control, ${ }^{* * a a} \mathbf{p}=0.01$ compared to control and case of $3^{\text {rd }}$ day

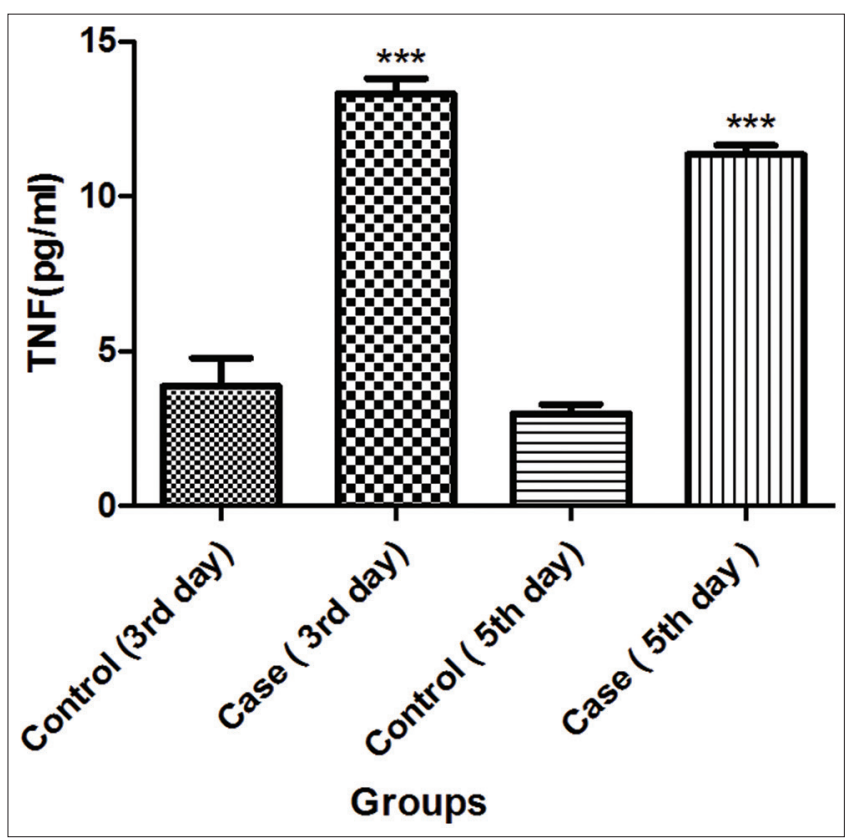

Fig. 2: The result of serum tumor necrosis factor-alpha levels of patients suffering from dengue infection. Data are expressed as mean \pm standard deviation, $\mathbf{p}<0.05$ is considered significant, ${ }^{* * *} \mathbf{p}=\mathbf{0 . 0 0 1}$ compared to control, ${ }^{* * a a} \mathbf{p}=\mathbf{0 . 0 1}$ compared to control and case of $3^{\text {rd }}$ day

In the current study, the levels of both IL- 6 and TNF- $\alpha$ were raised significantly during secondary stage of infection in cases compared to controls; however, IL- 6 levels dropped significantly on the $5^{\text {th }}$ day of treatment while TNF- $\alpha$ remained same suggesting more specific role of TNF- $\alpha$ as a sensitive biomarker during course of dengue infection which supports the results of similar studies [13-19].

Age and sex also have influence on course of dengue infection suggesting the male predominance in present study which is similar to literature [20].
Thus, the current study helped in understanding the role of proinflammatory cytokine and inflammatory mediators involvement during course of dengue infection. TNF- $\alpha$ could be a potential biomarker in understanding severity of dengue infection.

\section{CONCLUSION}

The study concludes that the IL- 6 and TNF- $\alpha$ plays a key role in understanding pathogenesis of severity of dengue infection, TNF- $\alpha$ being more sensitive in reaction to pathogen. However, further molecular studies are required in understanding the pathways involved and developing a suitable biomarker in establishing severity of dengue.

\section{ACKNOWLEDGMENT}

We would like to thank all our subjects who were part of our study.

\section{AUTHORS' CONTRIBUTIONS}

RD initiated and conducted study and SBS helped in the preparation of manuscript.

\section{CONFLICTS OF INTEREST}

The author(s) declare(s) that they have no conflicts of interests to disclose.

\section{AUTHORS FUNDING}

Self.

\section{REFERENCES}

1. Rodenhuis-Zybert IA, Wilschut J, Smit JM. Dengue virus life cycle: Viral and host factors modulating infectivity. Cell Mol Life Sci 2010;67:2773-86.

2. Stanaway JD, Shepard DS, Undurraga EA, Halasa YA, Coffeng LE, Brady OJ, et al. The global burden of dengue: An analysis from the global burden of disease study 2013. Lancet Infect Dis 2016;16:712-23.

3. Haider Z, Ahmad FZ, Mahmood A, Waseem T, Shafiq I, Raza T, et al. Dengue fever in Pakistan: A paradigm shift; changing epidemiology and clinical patterns. Perspect Public Health 2015;135:294-8.

4. Tahir U, Khan UH, Zubair MS, Bahar EM. Wolbachia pipientis: A potential candidate for combating and eradicating dengue epidemics in Pakistan. Asian Pac J Trop Med 2015;8:989-98.

5. World Health Organization. Dengue Guidelines for Diagnosis, Treatment, Prevention and Control. Geneva: World Health Organization; 2009.

6. Castillo-Macías A, Salinas-Carmona MC, Torres-López E. Immunology of viral infections with ahigh impact in Mexico: Dengue, chikungunya, and zika. Med Univ 2017;19:198-207.

7. Scheller J, Chalaris A, Schmidt-Arras D, Rose-John S. The pro-and anti-inflammatory properties of the cytokine interleukin-6. Biochim Biophys Acta 2011;1813:878-88.

8. Sriram BS, Ravichandra V. An experimental study evaluating the influence of quercetin on monosodium glutamate induced depression in Swiss albino male mice. Asian J Pharm Clin Res 2019;12:292-4.

9. Ober D, Nguyen TL, Shen L, Ha DQ, Huong VT, Benyoucef S, et al. Tumor necrosis factor alpha levels in plasma and whole-blood culture in dengue-infected patients: Relationship between virus detection and pre-existing specific antibodies. J Med Virol 1998;54:210-8.

10. Hober D, Poli L, Roblin B, Gestas P, Chungue E, Granic G, et al. Serum levels of tumor necrosis factor-alpha (TNF-alpha), interleukin-6 (IL-6), and interleukin-1beta (IL-1beta) in dengue-infected patients. Am J Trop Med Hyg 1993;48:324-31.

11. Juffrie M, Meer GM, Hack CE, Haasnoot K, Sutaryo, Veerman AJ. Inflammatory mediators in dengue virus infection in children interleukin-6 and its relation to C-reactive protein and secret phospholipase A2. Am J Trop Med Hyg 2001;65:70-5.

12. Kautner I, Robinson MJ, Kuhnle U. Dengue virus infection: Epidemiology, pathogenesis, clinical presentation, diagnosis and prevention. J Pediatr 1997;131:516-24.

13. Kittigul L, Temprom W, Sujirarat D, Kittigul C. Determination of tumour necrosis factor-alpha levels in dengue virus infected by sensitive biotin-streptavidin enzyme-linked immunosorbent assay. J Virol Methods 2000;90:51-7.

14. Kuno G, Bailey RE. Cytokine responses to dengue infection among 
Puerto Rican patients. Mem Inst Oswaldo Cruz 1994;89:179-82.

15. Kurane I, Ennis FA. Immunopathogenesis of dengue virus infections. In: Gubler DJ, Kuno G, editors. Dengue and Dengue Hemorrhagic Fever. London: CAB International; 1997. p. 273-90.

16. Kurane I, Innis BL, Nimmannitya S, Nisalak A, Meager A, Janus J, et al. Activation of $\mathrm{T}$ lymphocytes in dengue virus infections. High levels of soluble interleukin 2 receptor, soluble CD4, soluble CD8, interleukin 2 and interferon-gamma in sera in children with dengue. J Clin Invest 1991;88:1473-80.

17. Kurane I, Meager A, Ennis FA. Induction of interferon alpha and gamma from human lymphocytes bye dengue virus-infected cells.
J Gen Virol 1986;67:1653-61.

18. Lanciotti RS, Calisher CH, Gubler DJ, Chang GF, Vorndam V. Rapid detection and typing of dengue from clinical samples by using reverse transcriptase-polymerase chain reaction. J Clin Microbiol 1992;30:545- 51

19. Laur F, Murgue B, Deparis X, Roche C, Cassar O, Chunge E. Plasma levels of tumour necrosis factor alpha and transforming growth factor beta- 1 in children with dengue 2 virus infection in French Polynesia. Trans R Soc Trop Med Hyg 1998;92:654-6.

20. Malavige GN, Fernando S, Fernando DJ. Seneviratne SL. Dengue viral infections. Postgrad Med J 2004;80:588-601. 